\title{
Paleoindian occupation of the White Mountains, New Hampshire
}

\author{
L'occupation paléoindienne dans les White Mountains, au New \\ Hampshire (É.U.A.) \\ Paläoindianische Besiedlung der White Mountains von New \\ Hampshire
}

\section{Richard A. Boisvert}

Volume 53, numéro 1, 1999

Late Quaternary History of the White Mountains, New Hampshire and Adjacent Southeastern Québec

URI : https://id.erudit.org/iderudit/004771ar

DOI : https://doi.org/10.7202/004771ar

Aller au sommaire du numéro

\section{Éditeur(s)}

Les Presses de l'Université de Montréal

\section{ISSN}

0705-7199 (imprimé)

1492-143X (numérique)

\section{Découvrir la revue}

Citer cet article

Boisvert, R. A. (1999). Paleoindian occupation of the White Mountains, New Hampshire. Géographie physique et Quaternaire, 53(1), 159-174.

https://doi.org/10.7202/004771ar
Résumé de l'article

L'occupation humaine la plus ancienne dans les White Mountains date d'il y a environ 11 ka BP. L'ensemble des outils de pierre qu'on y a trouvés ont été taillés selon un style et une technique bien distincts qui les font ressembler aux artéfacts et aux assemblages reconnus comme étant paléoindiens à travers le nord de l'Amérique. Cette culture a duré pendant au moins un millénaire dans les White Mountains et a coïncidé, du moins en partie, avec le Dryas récent. On décrit ici sept sites paléoindiens et leurs assemblages d'arté- facts. Ces sites semblent correspondre aux principaux bassins versants et à être associés à d'autres sites paléoindiens très dispersés en dehors de la région. La clé d'interprétation de ces sites est l'identification des sources lithiques des Paléoindiens. La rhyolite locale a servi dans deux sites, Berlin et Jefferson, et le chert de la région de Munsungun Lake dans le nord du Maine a été importé. Le déplacement de ces matériaux lithiques à partir des White Mountains ou vers ces dernières permet d'avoir une certaine idée des déplacements et des contacts interrégionaux. La durée et l'extension de l'occupation paléoindienne dans les White Mountains est un témoignage d'une adaptation réussie à un climat difficile et variable, bien que les mécanismes de subsistance et d'établissement soient mal connus. L'auteur fournit des directions générales pour les recherches à venir, l'accent étant mis sur la chronologie et les reconstitutions environnentales.
Tous droits réservés C Les Presses de l'Université de Montréal,1999
Ce document est protégé par la loi sur le droit d'auteur. L'utilisation des services d'Érudit (y compris la reproduction) est assujettie à sa politique d'utilisation que vous pouvez consulter en ligne.

https://apropos.erudit.org/fr/usagers/politique-dutilisation/ 


\title{
PALEOINDIAN OCCUPATION OF THE WHITE MOUNTAINS, NEW HAMPSHIRE
}

\author{
Richard A. BOISVERT, New Hampshire Division of Historical Resources, 19 Pillsbury Street, Box 2043, Concord, New \\ Hampshire 03302-2043, U.S.A.
}

ABSTRACT The earliest human occupation of the White Mountains region occurred approximately $11,000{ }^{14} \mathrm{C}$ years ago. A suite of stylistically and technologically distinctive chipped stone tools have been found that correlate with similar artifacts and assemblages known across North America and identified as Paleoindian. This culture endured in the White Mountains for at least a millennium and coincided, at least in part, with the Younger Dryas climatic episode. Seven Paleoindian sites and their artifact assemblages are described. These sites appear to correlate with major river drainages and to articulate with widely separated Paleoindian sites outside the region. Key to the interpretation of these sites is the identification of the sources of the lithics used by the Paleoindians for their tools. Local rhyolite was acquired for use in two localities, Berlin and Jefferson, $\mathrm{NH}$ and chert from the Munsungun Lake region of northern Maine was imported. The movement of these lithics into and out of the White Mountains provides a perspective on inter-regional movement and contacts. The persistence and extent of the Paleoindian occupation of the White Mountains is a testimony to the highly successful adaptation to a harsh and variable climate, however the mechanisms of the subsistence and settlement patterns are poorly known. A broad outline of directions for future research is offered, with an emphasis on chronology and environmental reconstruction.
RÉSUMÉ L'occupation paléoindienne dans les White Mountains, au New Hampshire (ÉU.A.). L'occupation humaine la plus ancienne dans les White Mountains date d'il y a environ $11 \mathrm{ka}$ BP. L'ensemble des outils de pierre qu'on y a trouvés ont été taillés selon un style et une technique bien distincts qui les font ressembler aux artéfacts et aux assemblages reconnus comme étant paléoindiens à travers le nord de l'Amérique. Cette culture a duré pendant au moins un millénaire dans les White Mountains et a coïncidé, du moins en partie, avec le Dryas récent. On décrit ici sept sites paléoindiens et leurs assemblages d'artéfacts. Ces sites semblent correspondre aux principaux bassins versants et à être associés à d'autres sites paléoindiens très dispersés en dehors de la région. La clé d'interprétation de ces sites est l'identification des sources lithiques des Paléoindiens. La rhyolite locale a servi dans deux sites, Berlin et Jefferson, et le chert de la région de Munsungun Lake dans le nord du Maine a été importé. Le déplacement de ces matériaux lithiques à partir des White Mountains ou vers ces dernières permet d'avoir une certaine idée des déplacements et des contacts interrégionaux. La durée et l'extension de l'occupation paléoindienne dans les White Mountains est un témoignage d'une adaptation réussie à un climat difficile et variable, bien que les mécanismes de subsistance et d'établissement soient mal connus. L'auteur fournit des directions générales pour les recherches à venir, l'accent étant mis sur la chronologie et les reconstitutions environnentales.
ZUSAMMENFASSUNG Paläoindianische Besiedlung der White Mountains von New Hampshire. Die früheste menschliche Besiedlung der Region der White Mountains fand um vor etwa $11000{ }^{14} \mathrm{C}$ Jahren statt. Man hat eine Reihe von stilistisch und technisch gleichartig behauenen Steinwerkzeugen gefunden, die mit ähnlichen Artefakten und Sammlungen quer durch Nord-Amerika korrelieren und sie als paläoindianisch identifiziert. Diese Kultur dauerte in den White Mountains mindestens ein Jahrtausend und fiel zeitlich zumindest z.T. mit der klimatischen Episode des jüngeren Dryas zusammen. Sieben paläoindianische Plätze und ihre Artefakt-Sammlungen werden beschrieben. Diese Plätze scheinen den wichtigsten Flussbecken zu entsprechen und mit weitverstreuten paläoindianischen Plätzen außerhalb der Region zusammenzuhängen. Ein Schlüssel für die Interpretation dieser Plätze ist die Identifizierung der Herkunft der Gesteine, welche die Paläoindianer für ihre Werkzeuge benutzt haben. Lokaler Rhyolit wurde an zwei Orten benutzt, in Berlin und Jefferson, Feuerstein von der Munsungan LakeRegion in Nord-Maine wurde importiert. Der Transport dieser Gesteine in die White Mountains und aus innen heraus erlaubt einen Einblick in interregionale Bewegungen und Kontakte. Die Dauer und Ausdehnung der paläoindianischen Besiedlung der White Mountains ist ein Zeugnis für die überaus erfolgreiche Adaptierung an ein rauhes und variables Klima, wenn auch die ÜberlebensMechanismen und Siedlungs-Muster wenig bekannt sind. Der Autor gibt in groben Zügen eine Anleitung für künftige Forschungen, wobei er die Chronologie und die Rekonstruktion der Umwelt betont.

Manuscrit reçu le 20 août 1998 ; manuscrit révisé accepté le 11 décembre 1998 


\section{INTRODUCTION}

The White Mountains are within a distinct geographic region of New Hampshire, occupying approximately twenty percent of the land surface in the north-central portion of the state (Fig. 1). The contemporary definition of the White Mountains is coterminous with the White Mountains National Forest and in a broad sense this is an adequate description. From an archaeological perspective, the area has several consistent geographic features. First are the hills and mountains themselves. Their steep slopes, often laid bare to ledges and cliffs, and superior elevation contrast sharply with the far lower and gentler hills around them. Large ponds and lakes are essentially absent within the White Mountains and small ponds, 5 hectares in surface area or less, and marshes characterize the stable water bodies. As would be expected, the Mountains serve as the headwaters to a number of river systems. These are the Saco/Androscoggin, Merrimack and Connecticut. The brooks that feed these rivers are high gradient, fast flowing, and typically choked with boulders and cobbles. The orientation of the main stems of the streams, with a few notable exceptions, is on a north/south axis and parallels the spine of the Presidential Range which forms the core of the district. Although not especially high by global standards, the White Mountains are sufficiently tall and rugged so as to effectively impede nearly all modern east/west transit and constrain north/south travel through mountain passes, known in the regional vernacular as 'notches'. The contemporary highway system reflects these constraints with the major arteries of travel funneled through the notches. The only exception is the Kancamagus Highway, connecting the communities of Conway and Lincoln, which was begun as a Civilian Conservation Corps project in 1938 and whose construction was motivated by a desire to generate employment during the Great Depression. The modern highway system through the White Mountains closely follows the historic Native American trails as illustrated in the Chester Price map (1967) and, to the extent that this map is accurate, reflects patterns of travel and settlement established early in the prehistory of the region. It is important to note that the Price map exhibits the same low density of trails for early historic times as the contemporary highway system. The White Mountains are viewed as distinct, though not isolated, from the surrounding region by its physiography.

The archaeological record of the White Mountains and surrounding regions is subordinate to the glacial record. Human occupation was not possible until the last glacial ice was absent from the landscape and life forms necessary to sustain people had become established. In the northern White Mountains at Pond of Safety in Randolph, $\mathrm{NH}$, the earliest date is 12,400 BP (Thompson et al., 1996: 229). This sets a lower limit for a human presence, although the actual time of the earliest possible occupation would likely have been somewhat later. Severe weather conditions and lack of vegetation would have prohibited both the collection of plant resources by foragers or the hunting of game animals by hunters since the prey would have required their own vegetal nutrition. The time lapse between the final elimination of the glacial ice and the establishment of an environment that

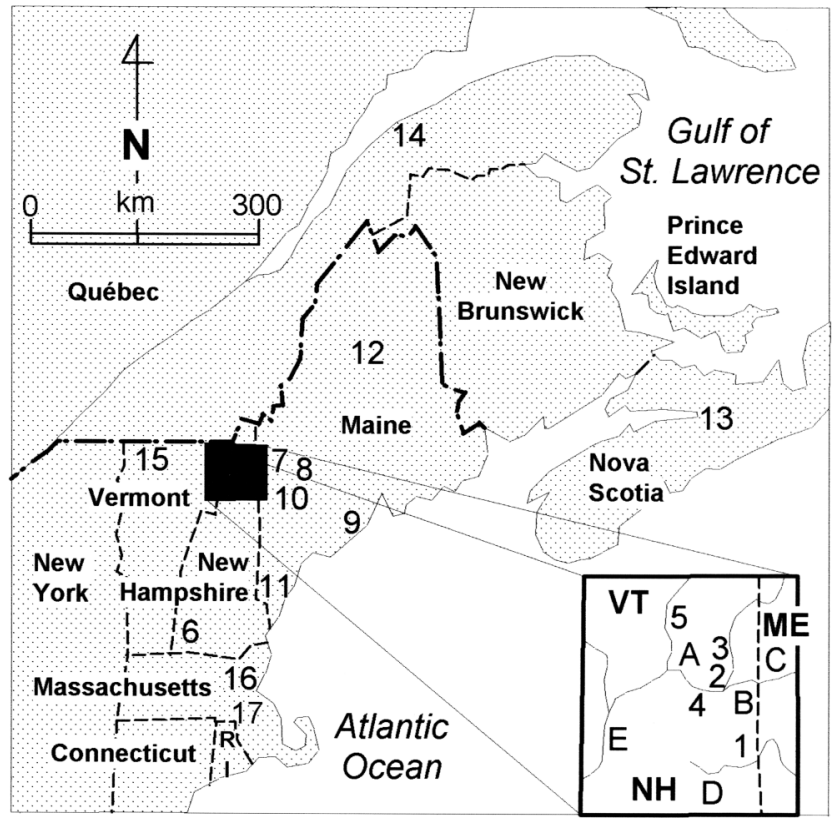

FIGURE 1. Location of archaeological sites and geographic areas. 1) Intervale, Conway NH;2) Randolph NH; 3) Mt. Jasper, Berlin NH; 4) Israel River Complex, Jefferson NH;5) Colebrook NH; 6 Whipple Site, Swanzey $\mathrm{NH} ; 7)$ Vail and Adkins Sites, Oxford Co. ME; 8) Michaud and Lamoreau Sites, Auburn ME; 9) Nicholas Site, Oxford ME; 10) Point Sebago Site, Sebago ME; 11) Spiller Farm Site, Wells Me; 12) Munsungun Lake Quarries and Workshops, Aroostook Co. ME; 13) Debert Site, Debert NS; 14) Rimouski Site, Rimouski, PQ; 15) Reagan Site, Highgate VT; 16) Bull Brook I \& II, Ipswich, MA; 17) Neponset Site, Neponset, MA. A. Israel River, B. Moose River; C. Androscoggin River, D. Saco River, E. Connecticut River.

Régions géographiques et localisation des sites archéologiques. 1) Intervale, Conway, New Hampshire ; 2) Randolph, New Hampshire ; 3) mont Jasper, New Hampshire ; 4) complexe d'Israel River, Jefferson, New Hampshire ; 5) Colebrook, New Hampshire ; 6) site Whipple, Swanzey, New Hampshire ; 7) sites Vail et Adkins, Oxford Co., Maine ; 8) sites Michaud et Lamoreau, Auburn, Maine ;9) site Nicholas, Oxford, Maine ; 10) site de Point Sebago, Sebago, Maine ; 11) site de Spiller Farm, Wells, Maine ; 12) carrières et ateliers de Munsungun Lake, Aroostook Co., Maine ; 13) Debert, Nouvelle-Écosse ; 14) Rimouski, Québec ; 15) site Reagan, Highgate, Vermont ; 16) Bull Brook I et II, Ipswich, Massachusetts ; 17) site Neponset, Massachusetts. A. Israel River, B. Moose River; C. Androscoggin River, D. Saco River, E. Connecticut River.

could have supported human occupation is unknown, but likely to have stretched for decades, if not centuries, after deglaciation. Consequently, human habitation may have been possible by 12,000 radiocarbon years ago ${ }^{1}$. Occupation between that time and the end of the Sangamon Interglacial at about 115,000 years ago is not considered possible due to the impact of the full glacial conditions during the Wisconsin Glaciation. A pre-Clovis occupation was not

1. It is now well established that radiocarbon assays exhibit a significant compression of dates during the critical period of the Younger Dryas. Independent confirmation from ice core data, varve counts, and analysis of coral growth rates indicates that radiocarbon dates are 1000 to 2000 years too young during this period, with the greatest distortion being between 10,000 and 11,000 radiocarbon years ago (Hall 1997: 1,4-7). 
possible in northern New England, even though it has been demonstrated in other parts of the Western Hemisphere.

The Paleoindian period in New England and the Maritime Provinces has been difficult to define because well dated sites are few and the associations between dated components and diagnostic artifacts are fewer still. Spiess, Wilson and Bradley (1998: 232-238) have summarized the available data and present a framework based on the available dates from the region melded with contextual data on the fluted point styles as developed from research in the Eastern Great Lakes and Mid-Atlantic regions. They present a chronology of the Paleoindian period as a "... good hypothesis in need of testing" (Spiess et al., 1998: 238). They define four phases spanning approximately a millennium (Table I) and summarized as follows. The earliest period contains the Bull Brook Phase and the Vail and Debert sites. The fluted points from the latter two sites are seen as distinct from Bull Brook on typological grounds. The authors hint that they may represent a separate cultural manifestation from Bull Brook while being essentially coeval with Bull Brook and other sites with more similar projectile points such as the Whipple site in Swanzey, $\mathrm{NH}$. The Bull Brook Phase is placed at 10,800-10,500 radiocarbon years BP and represented by points with parallelsided bases, prominent basal concavities and flute scars that are typically less than half the total length of the point. The Vail-Debert points are distinguished from the Bull Brook points in that the former are larger and have deeper basal concavities. The Bull Brook Phase is viewed as equivalent to the Gainey Phase in the Great Lakes region. The MichaudNeponset Phase is the second in the sequence, dating to about 10,200 radiocarbon years BP. The authors do not present a time range as the available dates tend to cluster closely around that date. The phase is seen as equivalent to the Parkhill Phase in the Great Lakes and represented by the Barnes type fluted point. This point style differs from the earlier varieties because they have narrower bases with less prominent basal concavities and have distinctive flared bases and exceptionally long flute scars, sometimes extending nearly the entire length of the points. The next phase is defined as Crowfield, and is derived directly from the phase of the same name in the Great Lakes region. Sites of this phase are few in New England and none have produced dates. The diagnostic artifact is the Crowfield point, which has a narrow contracted base and shallow basal concavity. The points are thinner and wider than the preceding Barnes points and frequently have multiple parallel flute scars. The final Paleoindian phase in their scheme is the Nicholas Phase typified by narrow based, expanded blade, unfluted points similar to the Holcombe type of the Great Lakes region. They date the phase to 10,100 to 10,050 radiocarbon years BP, implying either a short period for the Crowfield Phase or a temporal overlap among the phases. The seemingly short time span for the phases is explained by the authors as a function of the "... extreme compression of the radiocarbon time scale compared with calendar years" (Spiess et al., 1998: 238) and the actual time frame for the Michaud-Neponset and Nicholas Phases is actually along the order of 500 to 600 calendar years. The New England-
TABLE I

Temporal range of Paleoindian phases in the New England/Maritimes and Great Lakes regions

\begin{tabular}{lll}
\hline Temporal span & $\begin{array}{l}\text { New England } \\
\text { Maritimes }\end{array}$ & Great Lakes \\
\hline 10,800-10,500 BP & $\begin{array}{l}\text { Bull Brook } \\
\text { Vail/Debert }\end{array}$ & Gainey \\
circa 10,200 BP & Michaud-Neponset & Parkhill \\
unknown & Crowfield & Crowfield \\
$10,100-10,050$ BP & Nicholas & Holcombe \\
\hline
\end{tabular}

Maritimes sequence thus closely parallels the typologically defined cultural chronology of the Eastern Great Lakes, supplementing it with radiocarbon dates and including nuances of its own. This framework is adopted here as it supplies a useful point of departure for comparing the Paleoindian sites and artifacts from the White Mountains.

\section{THE PALEOINDIAN SITES}

The record of prehistoric archaeological data from all eras from the White Mountains is remarkably small. Within the White Mountains National Forest there has been only one systematic reconnaissance devoted to identifying prehistoric archaeological resources. This was a limited survey of upland ponds within the New Hampshire portion of the National Forest (Bayly and Boisvert, 1995). Although six sites were identified at five of the seven ponds surveyed, and two more were found on river terraces, only non-diagnostic debitage and fragmentary tools were recovered. Cultural resource management surveys conducted by US Forest Service personnel, principally for anticipated timber cuts, have identified abundant historic era sites but only two prehistoric sites in New Hampshire, and three prehistoric sites in Maine, and all of these were represented only by non-diagnostic debitage. A single isolated artifact, a fragment of an end scraper, was discovered by chance in a redeposited context at an Appalachian Mountain Club campsite and was recorded only because an archaeological field school was residing there. It is clear that the number of sites recorded is extremely small, especially in regard to the extent of the Forest, and it is assumed that it is not representative of the White Mountains as a whole. The total number of recorded prehistoric sites located within the National Forest stands at twelve and none of these are suspected of being Paleoindian.

Outside the boundaries of the White Mountains National Forest, but still within or adjacent to the White Mountains, field work has been more productive. The most intensive investigations have concentrated on the community of Conway, which stands at the southern end of the Mount Washington Valley, where intensive archaeological surveys have been conducted in anticipation of a large highway construction project. Numerous sites have been identified, but none with Paleoindian materials. Academically oriented research has been focused principally to the investigations in Berlin, $\mathrm{NH}$ at the Mount Jasper lithic source (Gramly and Cox, 1976; Gramly, 1980, 1984; Boisvert, 1992; Pollock et al., 1996), 
although recognition of its affiliation with Paleoindian was not recognized until very recently (Pollock et al., 1998). The other principal area of academic research has been the Israel River valley where the discovery of a fluted point in a disturbed context prompted subsequent investigations that defined that site as well as the identification of two additional Paleoindian sites (Bouras and Bock, 1997). In addition to this research, there have been occasional finds of artifacts later determined to be affiliated with Paleoindian. Two of these have come to the attention of the professional archaeological community and, though contextual data are limited, they are included in this presentation. All of the areas discussed below are in New Hampshire. The White Mountains extend into western Maine; however as yet we have no Paleoindian sites reported in that portion of the state.

The sites in the White Mountains with identified Paleoindian components are: an isolated fluted point find in an area known as Intervale in Conway; a similar recovery of a large bifacial knife in Randolph; the Mount Jasper Lithic Source in Berlin; and a cluster of three sites in Jefferson, known collectively as the Israel River Complex. Another site, located slightly beyond the boundary of the study area, is known as the Colebrook Site and is named after that town. The locations of most of these sites are not precisely reported in this study, in part because in two cases this information is not confidently known and, regarding the other sites, because confidentiality must be maintained in order to discourage unauthorized excavations by relic hunters who would effectively destroy the sites in an effort to acquire artifacts that might be considered valuable or otherwise collectable. The Mount Jasper lithic source is precisely identified since it has been widely known for over a century and the location has been published in several sources. The discussion of the two isolated artifact finds are presented in some detail as neither has been described previously in the archaeological literature and the value of their contribution lies in the description of the specimens themselves. The discussion of the more recently discovered sites is considered preliminary as they have been identified only recently and thorough analysis has not been completed. In fact, it is worth noting that prior to 1996, there was only one locality known and reported as Paleoindian in the White Mountains region. The expansion of the database has come from very recent research on new sites or re-evaluation of data from previously reported sites.

This paper seeks to coalesce the available data, summarize the current interpretations and offer a prospectus on future research. Even with the comparative explosion of new data on Paleoindian for the study area, we must still admit that the overall body of information is slim and that the conclusions reached may well be superseded by ongoing research and new discoveries. Still, the recent additions to our database are substantial and a statement of the current state of the art is appropriate. The order of presentation for each of the sites is by the chronology of their discovery.

\section{INTERVALE}

On September 11, 1888 Randall M. Erving, an aspiring artist, found a fluted projectile point "about $3 \mathrm{ft}$. from top of ground" at a locality known as Intervale Park in Conway, $\mathrm{NH}$. It is unlikely that he even remotely understood the nature of his find, and it is unfortunate that he did not more precisely record the location of his discovery. What little we do know is preserved in the records of the Smithsonian Institution because in October of 1893 he donated the specimen there. The point has been in the collections since that time and was recognized by a few researchers as a rare example of a fluted point from northern New England. It was included in a list of known fluted specimens from New Hampshire by Sargent and Ledoux (1973) and was on display at the Smithsonian during the 1980's and 1990's. After it was removed from exhibit, the point was obtained for the purpose of making a mold for manufacturing cast replicas by the archaeological educational firm of AMEYA, providing this author an opportunity to analyze the specimen in detail (Boisvert, 1998b).

The Intervale fluted point (Fig. 2) is made from Munsungun chert and is predominately dusky red in color, mottled with dark reddish gray. The specimen is complete, although it was evidently broken after its initial recovery (but before it was loaned for casting) and has been mended with glue. The point is fluted on both sides with multiple flutes on each. On one surface the flute extends $99.1 \mathrm{~mm}$, terminating $13.7 \mathrm{~mm}$ from the tip (the point is $115.3 \mathrm{~mm}$ long overall). After this fluting flake was removed, a subsequent, much shorter fluting flake was struck, reaching a maximum length of $27.7 \mathrm{~mm}$. On the other side a similar pattern is observed, however in this case three successive and successful attempts at fluting were achieved. The first flute extended
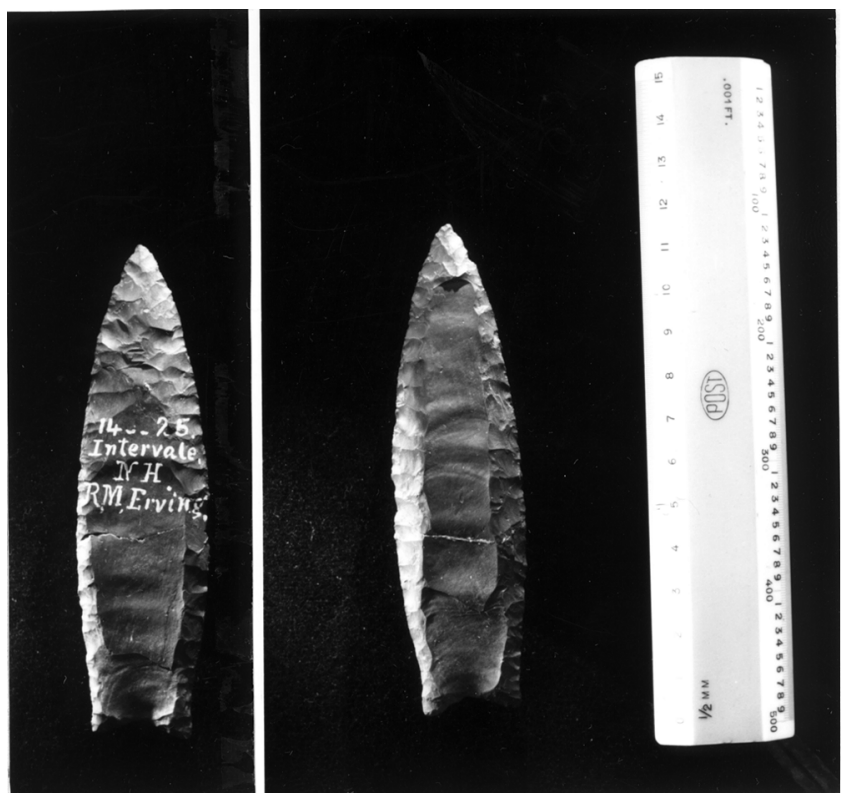

FIGURE 2. Fluted Point, Intervale, New Hampshire.

Pointe à cannelure (Intervale, New Hampshire). 
$88.1 \mathrm{~mm}$, followed by a second at $83.7 \mathrm{~mm}$ and ending with a short flute measuring $20.5 \mathrm{~mm}$. Examination of the ripple marks in the fluting flake scars indicates that the longer flakes were the product of so called "bending flakes" while the subsequent, shorter, flutes were the result of "conchoidal flakes", as defined by Pelcin (1998). The latter type of flake scar is characteristically shorter than the former and requires a distinctly different angle of blow for a successful detachment. The consequence of these flaking episodes was the manufacture of a point with extremely long flutes and a very thin $(4.2 \mathrm{~mm})$ basal thickness. It is very likely that the conchoidal flakes were struck intentionally to create the very thin hafting area. Notably, the extent of lateral edge grinding coincides with the length of the final fluting flakes. The base is indented and the lateral edges just above the base are slightly constricted while the rest of the sides are slightly excurvate, giving the point a "fishtail" appearance. The metric and morphological characteristics of the point place it comfortably within the Barnes type (Ellis and Deller, 1988). The point is very similar to Barnes type points reported by Carty and Spiess (1992: 27-33) at the Neponset site, Neponset, Massachusetts. One of these points has clear evidence of the removal of three channel flutes, the longest of which extends for almost the entire length of the point. The Barnes type is temporally intermediate to the earlier Gainey style and the later Crowfield style. The internal chronology of the Paleoindian in the Northeast is still unsettled, but an estimated age of 10,500 to 10,200 radiocarbon years ago would be considered acceptable.

The context of the Intervale point is fundamentally unknown. The museum accession card states that it was found "... at Intervale Park N.H." This is an area in the town of Conway on a high terrace overlooking the Saco River to the west and is situated in the Mount Washington Valley where several small streams converge to form the uppermost reach of the Saco River. This was the location of a small cluster of late 19th century cottages that were favored by summer tourists. The spectacular views of the cliffs and mountains were the principal attraction. This is also the junction of two north/south routes around the Presidential Range, one through Pinkham notch on the east and the other through Crawford Notch on the west. Occupation at Intervale during the Paleoindian period would have afforded a commanding view of any movement of game herds or other people along these natural travel ways and this may explain the attraction at this early date.

The vagueness of the provenience of the Intervale fluted point and the large scale disturbance of the landscape on the east side of the valley by modern development make it impossible to re-locate the original find. It does, however, confirm a presence of Paleoindian in the heart of the White Mountains and suggests that additional sites may be preserved at that locality and the region in general.

\section{RANDOLPH}

The town of Randolph, $\mathrm{NH}$, is situated on the drainage divide between the Connecticut River, by way of the Israel River, and the Androscoggin River, by way of the Moose
River. Directly south is the northern end of the Presidential Range and on the north is the Crescent Range. The vicinity of the watershed divide is known as Bowman and has served over the past century as a way station for travelers taking advantage of the east/west passage on US Route 2 between Lancaster on the west and Gorham and Berlin to the east. In 1947 Vyron D. Lowe, then in his 70's, recovered a biface from a gravel pit. The artifact was apparently an isolated find, although other less obvious items could have been overlooked in the context of the recovery. Lowe retained the artifact, refusing to donate it to a museum and it has remained in the possession of the Lowe family since.

The artifact (Fig. 3) is a large elliptical biface made on a very large flake and evidently thinned so as to reduce, but not completely eliminate, the curvature of the original flake. The raw material is of an unknown lithic resembling chert or a high quality rhyolite, and is very dark gray, almost black, in color. The specimen measures $147.2 \mathrm{~mm}$ long, $98.5 \mathrm{~mm}$ wide and has a maximum thickness of $15.8 \mathrm{~mm}$ near the striking platform end of the original flake. The surfaces of the biface exhibit well controlled percussion flaking reflecting two general varieties. Except for a portion which retains the unmodified initial flake interior surface, most of the surfaces exhibit large, broad flake scars which extend from the bifacial edges to the longitudinal midline and are up to $50 \mathrm{~mm}$ in length and up to $30 \mathrm{~mm}$ wide. They are suggestive of a broad ended soft hammer percussor, such as an antler billet. The flake scars reflect broad, thin flakes and most terminate in wide, shallow, hinge fractures with the remainder terminating in sharp or feathered edges. Subsequent to the removal of these broad invasive flakes, the margins were trimmed by a series of consistently short flakes, rarely exceeding $7 \mathrm{~mm}$ in length and usually less than $5 \mathrm{~mm}$ wide. Virtually all of these flakes terminate in hinge or step fractures. The bifacial edge of the specimen is sharp and the arrises of the shorter suite of flake scars are unworn. The arrises of the larger
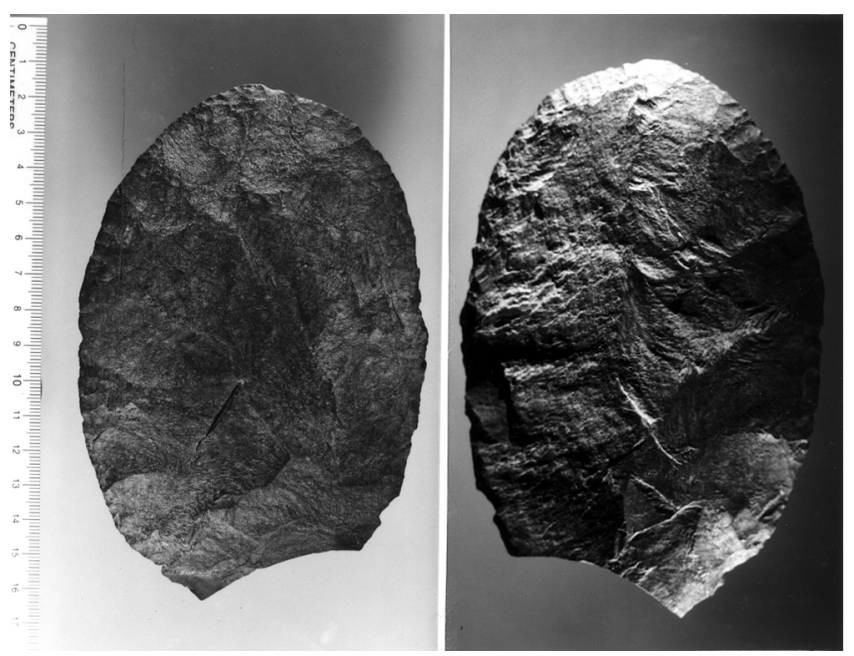

FIGURE 3. Lowe Biface, Randolph, New Hampshire.

Biface de Lowe (Randolph, New Hampshire). 
flake scars, however, exhibit substantial wear that can be observed unaided by magnification. In addition, several of the large flake scars are proportioned such that it appears that their original striking platforms would have been placed well beyond the existing margin of the bifacial edge. That is, the biface had been reduced in width substantially after the removal of these large flakes. On the basis of these observations, it appears that the biface had been significantly wider, and possibly longer, when it was first manufactured and that it has been reduced in size by subsequent marginal trimming. This trimming is interpreted as resharpening of the bifacial edge. It appears that the biface was evidently a broader and possibly longer tool that was used, dulled and resharpened repeatedly. This specimen may have been a butchering or flensing tool, used on a large animal, that was reduced in size as it was maintained over its use-life.

The biface is attributed to the Paleoindian on the basis of its similarity to other large Paleoindian bifaces. The principal comparison is to an artifact known as the Azicohas Biface. This artifact was discovered in 1937 near Azicohas Falls, Maine, on the Magalloway River in what is now Azicohas Lake. It has been identified as Paleoindian in age (Spiess, 1990) on the basis of its method of manufacture and source material, Munsungun chert. It measures $166 \mathrm{~mm}$ long, $141.6 \mathrm{~mm}$ wide and has a maximum thickness of $13.2 \mathrm{~mm}$, weighing $417.2 \mathrm{~g}$. However, it must be noted that the specimen is broken and that it was likely to have been longer in its original state. The specimen was broken along natural flaws in the material. It shares a pattern of manufacture with the Randolph specimen in that it has large, broad flake scars over much of the surfaces, while the margins exhibit short, steep retouch terminating in hinge fractures. Unlike the Randolph specimen, the large and broad flake scars all appear to originate at or very close to the bifacial edges. The Azicohas Biface thus appears to have been a tool very similar to the Randolph specimen, except that it was not subjected to resharpening, possibly because it was broken early in its use-life. The Azicohas specimen is larger and better crafted. This may be explained by the fact that it was made from a superior quality raw material that quite likely occurred in larger natural pieces.

Vyron Lowe's discovery in Randolph became known to the residents of the substantial summer colony there, many of whom were academics affiliated with prominent colleges and universities in the Northeast. One of these summer residents was Harry C. Hart who was evidently associated with the University Museum at the University of Pennsylvania. Hart attempted to attract interest in the artifact from various archaeologists and museums. Although unsuccessful, his efforts did initiate a round of correspondence over the next six years, in the course of which we are left with several tantalizing bits of information concerning the context of the find. In a letter dated September 24, 1948 to Froelich Rainey, then director of the University Museum at the University of Pennsylvania, Hart reported "To help you form a rough estimate of the possibilities, I can only say that the object was found in a gravel pit close to a height-of-land where the Israel river has its source, and not far from the base of Mount Adams, on the north side. From the topograhy (sic) one is led to infer that if the deposit was laid down by the Connecticut River, then it must have been in an age when the River was several hundred feet higher than at present. Mr. Lowe stated that the object lay at a depth of 21 feet... The gravel deposit is a large one, and was at one time worked commercially. It was through the medium of a commercial steam shovel that the object was uncovered. But it is no longer being so worked, and there is plenty left."

Five years later the cause had been taken up by John $Q$. Stewart of the Princeton Observatory, Princeton University. He requested a geological commentary from Marland P. Billings, then at Harvard University, regarding the geological nature of the gravels. Billings replied in a letter to Stewart dated February 11, 1953, "I am very familiar with the gravel deposit to which you refer as I have been past it many times and have gone into the pit on a few occasions. It is a kame deposited when the last ice sheet was melting away. At this time the ice was very rotten and full of depressions in which sand and gravel accumulated from a stream flowing eastward." Billings then went on to cite references of works by Richard P. Goldthwait on kame deposits in the vicinity. It is clear from a reading of the correspondence that the specimen was recovered from glacial deposits. The reported recovery from 7 meters below the surface, however, suggests that it had been found in a disturbed context.

The accumulated evidence strongly supports a Paleoindian affiliation for the Lowe Biface. The exotic raw material, large size, method of manufacture and similarity to the Azicohas Biface all argue for such a conclusion. The geological context is also supportive, but not conclusive. The find is presented here as being from a highly probable, but as yet not certain, Paleoindian context. Although discovered half a century ago and presented to the archaeological community as a significant find, it languished in obscurity until presented to the author while conducting research on Paleoindian sites in this region. As an isolated find it has limited value for interpretation, however within the broader regional context it helps establish a larger basis for evaluating Paleoindian resources.

\section{BERLIN}

The City of Berlin, $\mathrm{NH}$, is situated at the confluence of the Androscoggin and Dead rivers. The Androscoggin basin extends northeast to the Magalloway River whose headwaters define the boundary between northwestern Maine and Québec. The Androscoggin is a high energy river, flowing over a series of rapids and falls as it courses through the city to Cascade Falls which is located in adjacent Gorham, NH. This contrasts sharply with the sluggish, meandering flow of the Dead River, an underfit stream draining the sand choked Copperville Throughway. This valley trends northwest, eventually connecting with the Upper Ammonoosuc River, a tributary to the Connecticut, on the northern fringe of the White Mountains. Eight kilometers south of the Dead River on the Androscoggin is the mouth of the Moose River. Two kilometers further south is the Peabody River which 
rises at Pinkham Notch, the principal route of access directly south to the Saco Drainage. Berlin is therefore conveniently positioned to be accessible from several directions.

Poised over Berlin and overlooking the Androscoggin and Dead rivers from the northwest is Mount Jasper. The mountain is composed of Ordovician age Ammonoosuc Volcanics which are chiefly amphibolite and fine grained light-gray biotite gneiss (Billings and Fowler Billings, 1975: pl. 1). Laced through this matrix are a series of post-metamorphic dikes, the youngest of which is flow banded rhyolite. The inspiration for the mountain's name was undoubtedly derived from the dike which strikes across the cliff-like southwestern face and the character of the rock from the dike. Although dikes are common in the region-Billings and Fowler-Billings (1975: 76) recorded 241 dikes in the Gorham Quadrangleonly eight are rhyolite and all of these occur in close proximity to the Dead River and are on or near Mount Jasper. "This narrowly confined distribution of rhyolite dikes, as opposed to a wider distribution clearly indicates a small source area for the artifacts recovered from various archaeological sites. The importance here is that this constitutes a swarm of rhyolite dikes which are not widely distributed and which serendipitously crop out on thoroughfare between the Androscoggin and Connecticut River drainages." (Pollock et al., 1998) Thus far, only the one at Mount Jasper exhibits evidence of having been worked in prehistory.

The dike at Mount Jasper is composed of a very distinctive color banded spherulitic rhyolite which is micro- to cryptocrystalline. The spherules are small, 1 to $3 \mathrm{~mm}$ in diameter, and frequently aligned with the flow bands. These bands in unweathered specimens are alternately colored, according to the Munsell color charts, in shades of light olive gray (5 YR 5/ 2 ) with shades ranging from very pale orange (10 YR 8/2) to pale yellowish brown (10 YR 6/2) (Pollock et al., 1996). Weathered specimens, however, may reveal little or no banding and may be significantly lighter in color with shades ranging from pinkish white (7.5 YR 8/2) through pinkish gray (7.5 YR 6/2) to very pale brown (10 YR 7/4) (Boisvert and Dickinson 1992). Luster and surface hardness also vary dramatically with weathering. Specimens excavated from prehistoric lithic workshops at the base of Mount Jasper in mixed colluvial and alluvial deposits revealed that rhyolite artifacts from 30 to $35 \mathrm{~cm}$ below the surface were little altered in this regard but specimens from the $10 \mathrm{~cm}$ immediately below the surface were dull, porous and chalky to the feel (Boisvert and Dickinson 1992). That the deposits were relatively undisturbed is supported by the fact that the specimens in the intermediate levels were also intermediate in the spectrum of weathering. Spodic soils had developed in these deposits and the greatest weathering was clearly associated with the albic $(E)$ horizon and the least weathering in the deeper spodic (O) horizon. Weathering, therefore, should not be considered a reliable gage of relative age and may more accurately reflect post (cultural) depositional context.

The principal rhyolite dike has a width of nearly two meters and is flanked by smaller, parallel dikes that are approximately half a meter in width. At approximately $20 \mathrm{~m}$ in elevation below the summit there is a prehistoric adit which follows the dike horizontally into the mountain to a length of $9 \mathrm{~m}$, with a height of $6 \mathrm{~m}$ and a width of $2 \mathrm{~m}$. This adit and dikes on the summit were worked prehistorically and workshops are located both at the summit and at the foot of the mountain. Workshops are notoriously difficult to date, as well made, diagnostic implements would have been carried away from the site, leaving production waste and poorly formed rejects behind. Excavations in the 1970's did recover diagnostic Archaic and Woodland period projectile points that were evidently at the end of their uselife and were replaced by specimens manufactured at the site (Gramly, 1984). However, evidence for a Paleoindian occupation at the site was not identified. Determination of an early use of the resource is made not through recovery of data at the site, but rather through analysis of artifacts made of material from the site.

Hand specimen identification of cryptocrystaline rock is difficult and has been used with variable success to identify diagnostic artifacts made from Mount Jasper Rhyolite. Reports of artifacts made of Mount Jasper Rhyolite ranging from Early Archaic through Late Woodland (circa 9500 to 500 years ago) were found in a survey of the literature for the nomination of the site to the National Register of Historic Places (Boisvert, 1992: 159-161). At about the same time, Spiess (Spiess and Wilson, 1987; Carty and Spiess, 1992) identified a material at the Michaud Paleoindian site (Auburn, $\mathrm{ME}$ ) as "Neponset Rhyolite" based upon its common occurrence at the Neponset Paleoindian site in the town of the same name in eastern Massachusetts. This research recognized the distinctive features of the rock but acknowledged that the origin was unknown at that time. The source of the "Neponset Rhyolite" and the lack of data to support a Paleoindian usage of Mount Jasper were resolved simultaneously with X-ray diffraction analysis by Steven Pollock, U of Southern Maine. Comparisons from the margin to center of the dike indicated that the dike is mineralogically homogeneous but more importantly, the same tests indicated that Paleoindian fluted points recovered from Michaud and Neponset are from the same dike material found at Mount Jasper (Pollock et al., 1996: 247). Subsequently, X-ray analyses by Pollock have identified the presence of this material also at the Lamoreau site (Auburn, ME), the Nicholas site (Oxford, $\mathrm{ME}$ ), the Point Sebago site (Sebago State Park, ME) and the Spiller Farm site (Wells, ME), all of which are Paleoindian sites (Pollock et al., 1998). The weathered Paleoindian specimens went unrecognized because of their dissimilarity to the unweathered hand-specimen comparative samples.

Mount Jasper rhyolite has been documented at two Paleoindian sites recorded in Jefferson, New Hampshire [see discussion below]. Hand specimen analysis by Pollock (unpubl., 1998) of 141 tools and tool fragments from the sites identified 108 as spherulitic rhyolites. Comparison of variation in the spherules in the raw material samples from till sources in Jefferson and with samples from the adit on Mount Jasper allowed Pollock to distinguish between the two sources. Among the spherulitic rhyolite artifacts, 51 were identified as having most likely originated from Mount Jasper and the remaining 57 were identified as being from Jefferson New Hampshire. Thus, nearly half of the rhyolite specimens were 
imported to the site from Berlin. Two fragmentary point bases and a pair of conjoinable fragments of a fluted preform were identified as being from Mount Jasper and were recovered from the same locus at the Jefferson II site. No fluted points made from Mount Jasper were identified at the Jefferson III site, however more than half of the end scrapers were made from this material. Mount Jasper rhyolite constitutes a significant proportion of the material used for implements at the Jefferson Paleoindian sites.

The Mount Jasper lithic source must therefore be recognized as a Paleoindian site, even though there have been no documented components there. Intensive use over at least ten millennia has undoubtedly destroyed the original extraction areas at the source. The physical size of the source is large, extending for more than half a square kilometer and previous excavations have penetrated only a minuscule percentage of the area. Thus the potential remains for the discovery of Paleoindian workshops at Mount Jasper.

\section{JEFFERSON}

The town of Jefferson, $\mathrm{NH}$, is situated on the Israel River, flanked on the north by the Pliny Range and on the south by the Dartmouth Range. The valley is uncharacteristically broad and flat, compared to valleys of similar sized streams in the White Mountains. This is due in large part to the formation of glacial lakes in this valley at the end of the Pleistocene (Lougee, 1930; Thompson et al., 1996). As the glacial ice receded a lake formed in the upper portions of the valley, draining eastward through Randolph Notch and down the Moose River. When the ice retreated further, a spillway developed at a lower elevation at what is now Cherry Pond and drained southerly to glacial Lake Whitefield. When the ice finally expired, the river formed and completed its course northeasterly to the Connecticut. The age of the lakes and their temporal span are not precisely known, but they must post-date $12,400{ }^{14} \mathrm{C}$ yr BP. A radiocarbon date of this age was recovered from Pond of Safety in Randolph (Thompson et al., 1996: 229), indicating that the Pond had formed and organic matter had been deposited by that time. Dating of the successional lake stages has not been achieved nor has there been consensus on when this area of the White Mountains was completely ice free and suitable for human habitation, but date of 12,000 BP would seem reasonable.

Three Paleoindian sites have been identified in Jefferson. Their discovery was made as a result of both opportunistic and systematic reconnaissance by members of the New Hampshire State Conservation and Rescue Archaeology Program (SCRAP), a program directed by the NH Division of Historical Resources. The initial discoveries by Paul Bock, an archaeologist resident in Jefferson and member of SCRAP, were made in the fall of 1995 and the spring of 1996 when he inspected the roots of trees downed by an especially fierce storm (Bouras and Bock, 1997). The sites are relatively large, covering from half a hectare to four hectares, and have yet to produce any artifacts from later prehistoric eras. All three are relatively close together, fitting within a single square kilometer. None are situated near any existing pond, stream or wetland. Two of the sites (Jefferson I and II) would have been on or near the margin of the lower stage of the glacial lake. The proximity of the sites to each other, their similar site setting and artifact assemblages have led this author to identify them as the Israel River Complex (Boisvert, 1998a). Archaeological reconnaissance in this locality is incomplete and additional Paleoindian sites may quite probably be present and added to the Complex at a later date. Research is ongoing and interpretations will be modified and expanded.

\section{Jefferson I}

The Jefferson I Site (27-CO-28) was the first recognized as being Paleoindian when Bock discovered a basal fragment of a fluted projectile point (Fig. 4) that had been exposed by a fallen tree. The site is situated on a low rise composed of very stony till. The soils are sandy with abundant gravel inclusions. The current vegetation is dense second growth pine forest, but prior to the establishment of forests in the early Holocene the site would have had a commanding view of the Israel River valley. Upon discovery, the locality was mapped and additional lithic artifacts, principally debitage, were collected. More systematic investigations continued in April 1996. At that time soils from seven rootballs were sifted, fourteen $50 \mathrm{~cm}$ by $50 \mathrm{~cm}$, and six $1 \mathrm{~m}$ by $1 \mathrm{~m}$ test pits were excavated and sifted. No cultural features were identified in the excavations. Field investigations recovered data suggesting that two activity areas, separated by approximately 30 meters, were present. Dense underbrush and fallen trees prohibited successful systematic delineation of activities areas or artifact concentrations and additional such areas may exist at the site. Shortly after this testing operation was completed attention to this site was diverted by potential threats to one of the other sites in the complex. Since the owner of the Jefferson I site has indicated that there are no threats to this site, active research has been

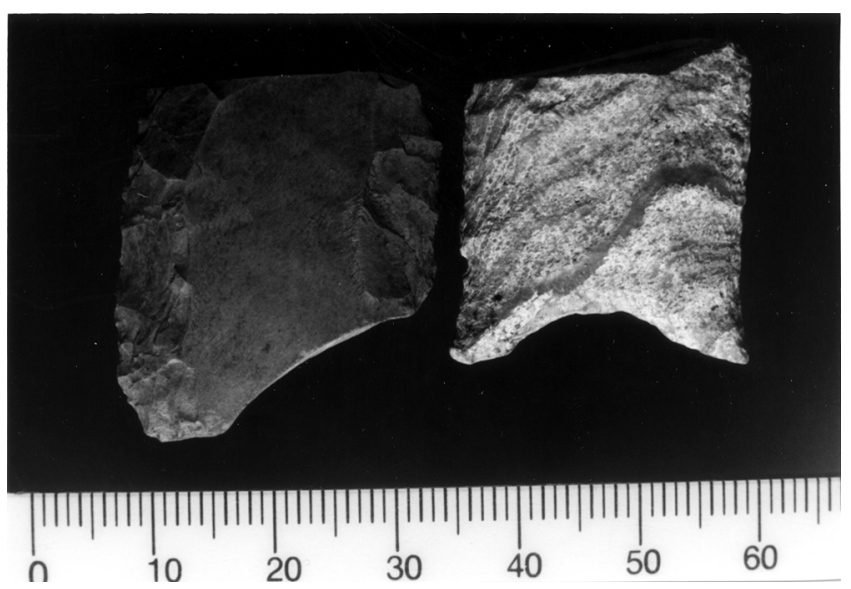

FIGURE 4. Fluted Points from Jefferson I (27-CO-28). Left, point found in tree throw; Right, point recovered in excavations, Jefferson, New Hampshire.

Pointes à cannelure en provenance de Jefferson (27-CO-28). À gauche, pointe mise au jour par la chute d'un arbre; à droite, pointe recueillie dans un trou (Jefferson, New Hampshire). 
temporarily suspended. Analysis of the Jefferson I site is therefore incomplete. Some preliminary observations can be made, however.

Abundant debitage was recovered at the site as well as several marginally retouched cutting tools. Side and end scrapers have not been recognized in the assemblage. More important, however, was the recovery of a second fluted point (Fig. 4) at a depth of $31 \mathrm{~cm}$ below the surface from a test pit. This test pit was located adjacent to the same fallen tree where the first fluted point was found. These specimens have been described in detail elsewhere (Bouras and Bock, 1997: 53-54) and are summarized as follows. The first specimen is made from a very fine grained, cryptocrystaline material which has been patinated. The material type of the specimen is undetermined. The basal edge of the point is broken, as well as the midsection. Only the lateral edges and a portion of one basal corner remain intact. The sides are slightly excurvate and exhibit well controlled pressure flaking, some of which occurred after the removal of the channel flutes. Initially, it was thought that the point was broken while on the haft, however the lateral edges lack grinding, suggesting that it may have been broken prior to completion. The fragmentary nature of the specimen is such that it is not possible to confidently assign it to a specific style of fluted point. The second specimen does retain enough of its morphology to make a comparison. The basal area is intact and exhibits a slightly incurvate base and narrow constrictions on the lateral edges just above the base. The lateral edges and the base exhibit light to moderate grinding. The morphology of the specimen is consistent with the Barnes type point (Ellis and Deller, 1988) and it is very similar to Barnes-like points from the Neponset site (Carty and Spiess, 1992: 27-33) and is virtually identical to the equivalent portions of the Intervale Fluted Point. Also recovered from the Jefferson I site, at a locality 30 meters distant from the fluted points, was a striking platform end of a channel flake. It is made from a dusky red chert with very fine black veins and, macroscopically, appears to be Munsungun chert. The specimen is small, barely $12 \mathrm{~mm}$ long, but clearly exhibits careful pressure flaking and heavy grinding to shape the striking platform. The platform is lipped and there is no observable bulb of percussion, suggesting that this channel flake was a "bending" flake. This channel flake would have had the so-called "nipple-like" striking platform which is associated with Barneslike points described at the Neponset site (Carty and Spiess, 1992: 27). The available evidence, though meager, supports an assignment of the Jefferson I site at least to the Middle Paleoindian Michaud-Neponset Phase.

The overwhelming majority of the raw material at the Jefferson I site was initially interpreted as having come from the Mount Jasper. The macroscopic features of color, luster, spherulitic banding and patination all mimicked the flow banded rhyolite from that lithic source which is only $24 \mathrm{~km}$ to the east. Specimens from Jefferson I identified as most closely resembling the Mount Jasper material were submitted to Steven Pollock for comparative analysis. X-ray diffraction revealed that while the material is very similar to that from Mount Jasper, it none-the-less possesses mineralogical characteristics which render it distinct. The Jefferson rhyolite contains small amounts of mica not present in any of the Mount Jasper samples, suggesting that the Jefferson material was derived from essentially the same molten rhyolitic parent material but that it had a slightly longer cooling period (S.G. Pollock, personal communication). The source of this subtly different rhyolite has not been identified, but recovery of unmodified rhyolite from till soils at the Jefferson II site suggests that it may have a local bedrock origin.

Based on preliminary analysis, the Jefferson I Site has a Michaud-Neponset Phase component with Barnes type projectile points being used, and possibly made, on site. Exotic as well as local material is being used, and the principal activities evident at the site are the manufacture of chipped stone tools, including fluted points, and probably hunting. Contact, either direct or indirect, was made with northern Maine (Munsungun) and possibly eastern Massachusetts (Neponset). Group size or duration of stay cannot be assessed with the limited data and it is virtually certain that other dimensions of site function remain to be discovered.

\section{Jefferson II}

This site was discovered by surface collections and arbitrary shovel test pit excavation prior to the identification of the Jefferson I site. No diagnostic artifacts were recognized initially, however. After the fluted points were recovered from the later site, the debitage was re-examined from Jefferson II and a channel flake and piece esquillee were found in the assemblage along with several flakes of exotic raw material. The channel flake indicated that a Paleoindian component was present. Shortly after this identification was made, the landowner placed the site on the market for sale. Confronted with the possibility that the site might be purchased and developed, the decision was made to give this site the highest priority for field work. The 1997 SCRAP field school was then scheduled for this site. Just prior to the initiation of the field school, a basal fragment of a fluted point was discovered, further confirming the presence of a Paleoindian component.

The research focused on two excavation blocks, one covering $12 \mathrm{~m}^{2}$ in a sand lens and another consisting of $35 \mathrm{~m}^{2}$ in till deposits. The larger block produced an additional six fragments of fluted points (two of which refit together), seven more channel flakes, six more biface fragments of probable fluted point preforms, seven unifaces, fifteen retouched flakes and in excess of 10,000 waste flakes. The materials from the smaller excavation yielded barely 250 flakes and a single tool fragment, an end scraper. Ground penetrating radar was used to map the lens and the sand deposits were found only within a 60 meter long, 10 meter wide area and extended to a a depth of 2 meters. Thinly banded clay and silty clay was found under the sands. The sand unit consisted of loose homogeneous medium sands with occasional fist sized pebbles in the upper 80 to $100 \mathrm{~cm}$ which overlay compact sands that exhibited clearly defined ripple marks. The lens was interpreted as having been laid down by glacial meltwater draining down into the Israel River Valley. Debitage was found within the homogeneous sand but no arti- 
facts were recovered in the compact rippled sand. No cultural features were identified in this sub-area. There was no compelling evidence for deeply buried, stratified deposits. Although artifacts were found up to a meter in depth, it is probable that the deeper materials were introduced by bioturbation. The artifacts in the till deposits were much more extensive and intensive. In addition to the block excavations, seven 1 meter square test pits and $7550 \mathrm{~cm}$ by $50 \mathrm{~cm}$ shovel test pits were dug. All of the 1 meter pits and 53 of the 59 shovel test pits were placed in till and contained artifacts, while 16 shovel test pits were excavated in the sand, of which only one was culturally sterile. The density of debitage was, on average, more than ten times greater in the till than the sand and the till accounted for more than $95 \%$ of the surficial deposits. The difference in density of materials between the sandy and till sub-areas was marked and unexpected since Paleoindian sites in New England are almost always associated with sandy soils (Wilson and Spiess, 1990: 23-24).

Paleoindian is the only prehistoric component identified at the site. No diagnostic artifacts from later prehistoric cultures have been recovered, and a thin scatter of early 20th century trash has been found only within the Ap horizon. Among the fluted specimens (Fig. 5), four are complete enough to be assessed for their similarity to accepted early and middle Paleoindian point styles. The large fluted preform fragment (recovered in two pieces) and fluted tip fragment lack diagnostic features which would allow for satisfactory comparison. The olive gray Jefferson rhyolite base has a deep basal notch, essentially straight sides and manufacturing characteristics considered typical for the points at the Gainey type site (Simmons et al., 1984). A small basal corner fragment, made of olive gray Munsungun Chert, is also deeply indented and straight sided, suggesting a similarity to Gainey points. A dusky red Munsungun chert basal corner fragment, found in the same excavation unit as the olive gray fragment, exhibits a similarity to the Barnes style point with its slight constriction just above the base and resulting basal "ear". The larger specimen made from the local Jefferson rhyolite shares this characteristic and also resembles the Barnes style. The fluted specimens from the Jefferson II site therefore reflect attributes of both Early (Gainey) and Middle (Barnes) Paleoindian projectile points. However, their fragmentary condition and small sample size impose great caution on our interpretations and recovery of additional specimens or refitting fragments would improve our interpretations.

A single radiocarbon sample has been processed from Jefferson II but has been of little help at determining the age of the site. A fragment of wood charcoal was obtained $46 \mathrm{~cm}$ below the surface in the till deposits in the large excavation block. The fragment of charcoal was situated in the soil matrix $12 \mathrm{~cm}$ from a tip of a bifacially worked preform. Recovered in the same soil as the sample were four very small flakes of what appears to be a high quality translucent white chert or chalcedony. The AMS date (Beta-108465) is $8570 \pm 60$ radiocarbon years. The calibrated date is $7550 \mathrm{BC}$, or 9600 years ago. The date is more than a thousand years too young to be

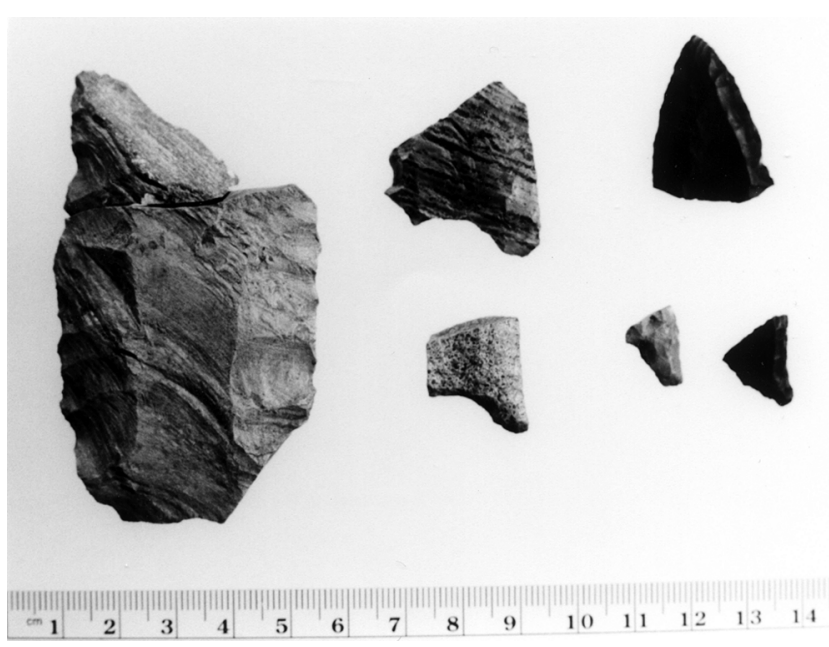

FIGURE 5. Fluted Points from Jefferson II (27-CO-29), Jefferson, New Hampshire.

Pointes à cannelure en provenance de Jefferson II (27-CO-29), Jefferson, New Hampshire).

reasonably associated with the fluted points found at this site. This implies that either the site is multi-component or that the carbon sample is from a non-cultural origin. On the basis of the existing data, the latter explanation is the most likely since we have yet to recover any Plano-like or Early Archaic diagnostic artifacts from this site.

The debitage and tool fragments recovered from the site reflect a range of activities. Chipped stone tool manufacture is the most well represented. Waste flakes overwhelming dominate the inventory and all but five bifacially flaked specimens were broken in manufacture. All stages of manufacture are represented in the assemblage, from initial reduction of raw material into usable cores, to production of simple bifacial preforms, through well thinned and shaped tools, to resharpening of worn edges. One of the primary goals of the tool manufacture was the production of fluted points. Two of the six examples of fluted pieces at the site were clearly broken in manufacture; one is the olive gray Jefferson rhyolite basal segment and the other is a large preform, fluted on both sides and recovered in two pieces. The debitage mirrors the full trajectory of reduction, including the fluting of projectile points as indicated by the channel flakes. Projectile points were evidently being broken in use. Three basal segments with well ground edges were recovered and appear to be fragments removed and discarded from the haft of the spears or darts, leading to the interpretation that they were broken while hunting nearby. The recovery of end scrapers and a piece esquillee (broken in use) strongly suggests the manufacture of items from hard organic material such as antler, bone or wood. Retouched flakes and side scrapers infer the processing of soft organics such as meat, hides or bark. The distribution of the artifacts within the site has not been assessed in detail, but initial review does not reveal any segregation of tool types or classes of debitage into task specific sub-areas. The preliminary interpretation is for the use of the site by at least one family band, executing a variety of domestic tasks and supported by hunting local game. 
Given the size of the site, it is likely that it was repeatedly visited but since the extent of the excavations are proportionately very small, it is not possible to estimate the size of the groups or the extent (temporal or spatial) of the occupations.

The raw material used at the site provides some significant insights on the site function and relationship to other areas. At least $98 \%$ of the debitage is made from the locally available Jefferson rhyolite. The bedrock source has not been identified, however a $40 \mathrm{~kg}$ till boulder was found at the site which exhibited a sizable rhyolite intrusion on a coarse syenite matrix. This syenite accounts for most of the till fabric at the site and originates in the Pliny Range and was likely transported only a few kilometers. The rhyolite used by the occupants could have been harvested directly from the till, from nearby outcrops, or both. On site acquisition is strongly suspected, as thick cortical flakes(indicative of initial processing of raw material) are common in the assemblage. If the vegetation on the site were sparse or absent then it would have been relatively easy to find the raw material. Encampments at the site might have been influenced by this resource and account for the placement of the tool making areas not only at the site in general, but also more specifically on the till deposits.

The exotic raw materials speak more to where the site inhabitants had been prior to occupying the site. Identification of exotic cryptocrystallines is problematic, at best, however recognition of at least some varieties of Munsungun chert is considered to be reliable. Other exotic materials are identified as such by virtue of their absence in the local or regional geology. Thus, a greenish chert channel flake is considered exotic because that material is not reported in the local bedrock nor has it been observed in the till deposits. Exotic raw material accounts for less than $1 \%$ of the debitage but for $50 \%$ of the fluted points and preforms. The two basal "ears" and the fluted tip are Munsungun chert. This strongly suggests that people were arriving at the site with points made elsewhere and that they were rejuvenating the points once they arrived and were replacing unrepairable broken points with new ones made on site. This interpretation is support by the recovery of two "ears" (made from different varieties of Munsungun chert) less than a meter from two Jefferson rhyolite channel flakes. A Munsungun connection, either direct or indirect, is evident. Identification of other contacts await identification of the other raw materials. Contact with other regions would have been facilitated by the presence of the site on the east/west corridor afforded by the Israel River to Randolph Notch and along the Moose River.

\section{Jefferson III}

This site was discovered initially from materials exposed by a tree fall. As with the Jefferson I site, it was situated entirely on till deposits and would have had a commanding view of the valley in a treeless environment. Disturbance by plowing was not observed at the site, but the very irregular cradle and knoll micro-topography made it evident that the deposits would have been disturbed, at least to some extent, by tree growth and tree falls.
A channel flake of dusky red Munsungun chert and the midsection of a parallel sided, collaterally flaked, biface fragment (Fig. 6) were recovered along with non-diagnostic debitage in the tree fall. Shovel test pits were excavated along the broad, loaf-shaped ridge to identify boundaries of the site which covers at least a hectare. More debitage was found along with a side scraper, retouched flakes and another channel flake of very dark gray Munsungun chert. On the basis of the channel flakes, the site was identified as Paleoindian and incorporated in the Israel River Complex. Subsequent to this determination, a woods road was created to remove fallen timber from the site. Erosion triggered by this action revealed additional debitage approximately $80 \mathrm{~m}$ from the initial finds. A test trench was excavated along the road in 1997 to explore the depth and extent of the newly defined areas of the site. Additional abundant debitage, primarily Jefferson rhyolite but also including a small percentage of the dusky red Munsungun chert, and four triangular end scrapers (Fig. 6) were recovered. A preliminary assessment of this site indicates a greater emphasis on cutting and scraping tools than in the other two sites in the complex. The area investigated is quite small, however, and the potential for error due to sampling bias or inadequate sample size is substantial.

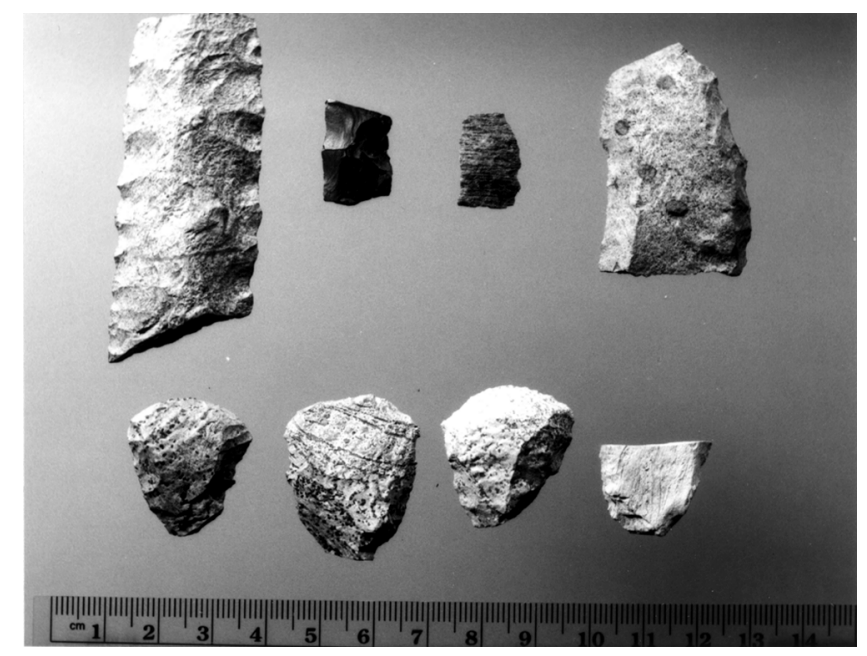

FIGURE 6. Lithic artifacts from Jefferson III. Top Row- Locus 1- Left, Biface midsection; Center Left and Center right, Channel Flake Fragments; Right, Uniface fragment, Bottom Row- Locus 2- End Scrapers, Jefferson, New Hampshire.

Artéfacts lithiques en provenance de Jefferson III. Rangée supérieure : locus 1- à gauche, partie centrale d'un biface : au centre, fragments d'éclats rainurés ; à droite, fragment unifacial. Rangée du bas : locus 2- grattoirs, Jefferson, New Hampshire.

The parallel sided biface fragment presents difficulties in interpretation. It can be viewed either as a Late Paleoindian non-fluted projectile point fragment or as a fluted point preform which was broken in manufacture prior to removal of the channel flakes. The parallel sided morphology and collateral flaking support the non-fluted point conclusion. The flaking pattern and cross-section indicate that the biface was broken in manufacture. One surface is convex and exhibits 
twice as many flake scars as the other surface, which also has a well defined angular medial ridge. This suggests that the piece may have been broken prior to final thinning. The ridged-convex cross-section is documented as a variety of fluted point preform morphology. Mounier et al. (1993) reported on a small knapping station where the focus was on fluting several preforms. "The analysis of channel flakes demonstrates a pattern of fluting bifaces with asymmetrical cross-sections. First, the flatter, or lenticular face of the biface was fluted with a single channel flake. Then, the second face, containing a distinct medial ridge, was fluted by removal of multiple channel flakes." (Mounier et al., 1993: 18) The recovery of the Jefferson III biface fragment in loose context with a channel flake indicates that fluting was carried out at the locality and that the hypothesis that the specimen was broken prior to (or during) fluting has merit. Alternatively, one would be required to argue that both a Late Paleoindian component and an earlier Middle or Early Paleoindian component were present at the same location on the site. Only the recovery of a larger body of data from secure context can resolve this question.

The Jefferson III site, like the other two nearby Paleoindian sites, exhibits a strong use of locally available rhyolite to manufacture Paleoindian tools. Exotic raw material is present at the site, but only as flakes from the final steps of tool manufacture or subsequent rejuvenation. The site is strategically perched on a gentle hillside overlooking the Israel River valley and situated in till soils. The distribution of artifacts is spatially broad and appears to be in relatively concentrated loci distributed within the site. These loci may be functionally discrete as well. The temporal extent of the occupation is unclear. Fluted points were present, at least as tools in the process of manufacture, supporting the conclusion that there was a Middle or Early Paleoindian occupation. There is the potential that a Late Paleoindian occupation may have been represented as well. If so, then there may have been a continuity of site use over a substantial length of time and through a period of technological and cultural transition. Alternatively, the site may represent either a very large single episode of habitation or multiple visits by small bands returning to the same general locality over time. The inventory of diagnostic materials from the site may be relatively sparse, but it does raise a number of significant research questions.

The Israel River Complex is a significant addition to the body of data on the Paleoindian presence in the White Mountains. It is composed of at least three large habitations that, in the aggregate, represent a consistent and repeated use of the area at this early time period. The sites, to date, appear to be exclusively Paleoindian with no later re-occupation. This in itself may be significant. The environmental setting changed so much with the onset of the contemporary climatic regime that the conditions that attracted Paleoindians to these sites may not have been a factor for later occupants. There may have been a hiatus of occupation in the valley (and region?) or Early Archaic sites may have been established in other localities along the Israel River. The hypothetical abandonment of the site by later inhabitants of the valley may have been related to the change in vegeta- tion. If the location of the Paleoindian sites may have been selected because of the presence of good quality workable stone exposed on the surface of the till deposits in the absence of thick vegetative cover then perhaps the establishment of the denser Holocene forests over the landscape effectively obscured the raw material. Visiting bands could no longer casually collect the rhyolite from the surface, thus no longer attracting them to these places and leading them to select other sites for encampment. For whatever reason, at the end of the Pleistocene there was a major presence of Paleoindian people in this valley in White Mountains. Explanation of occupations at the site and regional level must depend on more extensive research not only on Paleoindian sites but also on later Archaic and Woodland sites.

\section{COLEBROOK}

The most recently recorded Paleoindian site in northern New Hampshire is not in or immediately adjacent to the White Mountains, but its location and setting in Colebrook, $\mathrm{NH}$, is sufficiently close that it is relevant to the regional consideration. Known as the Colebrook Site (27-C0-38), it was identified as part of a survey in anticipation of the construction of a natural gas pipeline (Bunker et al., 1997), and because of its significance it was bypassed and not impacted by pipeline construction. The site is multi-component, with Archaic occupations present on the same terrace. These occupations are horizontally segregated from the earlier component and are represented by Archaic projectile points and a suite of lithic raw materials, principally quartz and rhyolite, that are different from the lithics from the Paleoindian component. The site is situated near the northern foothills of the White Mountains on an outwash terrace composed of gravely and sandy deposits overlooking the Connecticut River valley.

Archaeological investigations were conducted at the Colebrook site to fulfill requirements of federal regulations related to the construction of the gas pipeline. This included excavation of two contiguous one meter squares and six $50 \mathrm{~cm}$ square shovel test pits at one locus that proved to be Paleoindian in age. This was determined on the basis of the recovery of channel flakes made from chert and a date on minute charcoal fragments extracted from the fill of a hearth feature. The AMS date obtained is 10,290 \pm 170 radiocarbon years before present (Bunker et al. 1997: 20). Eight channel flake fragments (two of which conjoin) were recovered in relatively close proximity to the hearth along with a moderate amount of secondary reduction debitage. The channel flakes (Fig. 7) are all from exotic black or very dark gray chert, at least one of which exhibits very dark banding similar to some varieties of Munsungun chert from the Norway Bluff exposures. Macroscopic variation in the luster and groundmass suggests that more than one variety of chert may be represented in this collection. Also included in the debitage, but not among the channel flakes, are examples of a fine grained gray quartzite, possibly from sources to the west in Vermont. The only potentially local variety of raw material present are several primary reduction flakes of a pinkish volcanic stone that may have been derived from local cobbles. The bulk of the collection from this locus is made from high 
quality exotic raw material and contrasts sharply with the assemblages from the Archaic loci at the site. The one by two meter test pit also produced 12 circular stains, 3 to $5 \mathrm{~cm}$ in diameter and 3 to $10 \mathrm{~cm}$ deep and were encountered 50 to $63 \mathrm{~cm}$ below the surface. The excavators interpret these as post or stake molds in two intersecting arcs aligned around the hearth feature (Bunker et al., 1997: 20). They extrapolate the pattern to reflect a potential structure with a roughly circular diameter of approximately three meters.

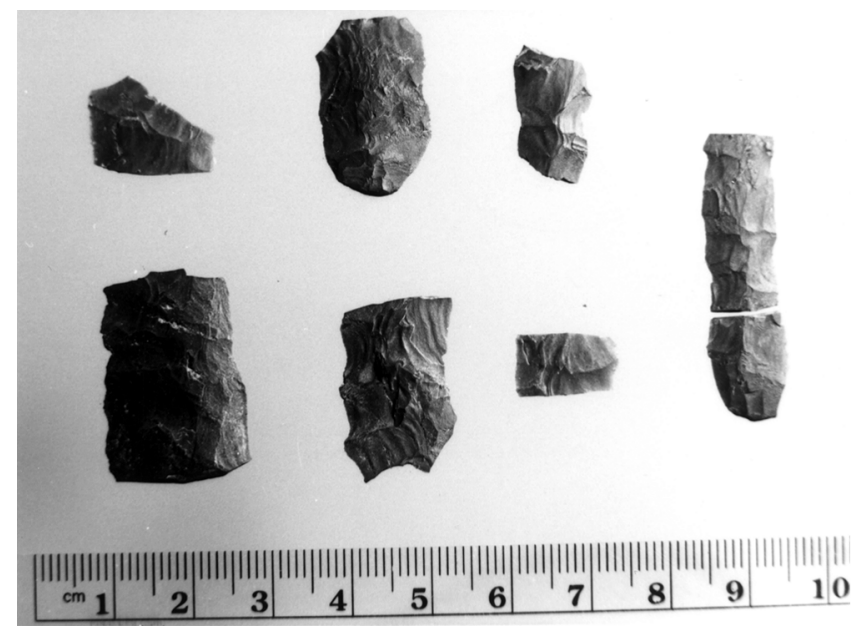

FIGURE 7. Channel Flake Fragments from the Colebrook Site (27-CO-38), Colebrook, New Hampshire.

Fragments d'éclats rainurés du site de Colebrook (27-CO-38), au New Hampshire.

The Colebrook Paleoindian locus is interpreted as a short term, single episode encampment by a small group where the most visible activity was the end stage manufacture of fluted points. Retouched flakes and scrapers are lacking in the assemblage and the only tool fragment recovered is a small black chert biface fragment which may have been from the tip section of a projectile point or knife. The area of the Paleoindian locus is small, seemingly no more than $25 \mathrm{~m}^{2}$ in extent. The very narrow range of variability in the exotic raw material and functions at the locus, plus the constrained distribution of artifacts argue forcefully that this was a camp occupied on a single occasion by a few widely traveled hunters. The Colebrook locus contrasts sharply with the Jefferson sites and the Mount Jasper lithic source. The nearest other Paleoindian sites are the Vail, Atkins and affiliated sites (Gramly, 1982, 1984, 1988) some $40 \mathrm{~km}$ east in Maine on the Magalloway River. Here too the differences are striking with larger numbers of people present there, engaged in intensive hunting and domestic activities. Because the investigations of the Colebrook site were suspended when the decision was made to avoid construction on it, there is no certainty that the entirety of this early occupation was identified. Other Paleoindian components may be present and would elaborate on, if not alter, the interpretation of the site. Regardless, the Colebrook Paleoindian site, though minimally investigated, represents a substantially different type of site and as such has the potential to significantly expand our understanding of the Paleoindian occupation of the larger region.

\section{COMPARISONS}

The Paleoindian sites of the White Mountains are relatively few in number. and consequently it is difficult to extract valid and meaningful statements that reflect their similarities and differences. Still, a cautious appraisal can reveal some potentially significant patterns and, having recognized these patterns, the differences among the sites may be highlighted and brought into focus for further research.

All of the site localities are to be found on or overlooking the streams and rivers of the region, and it appears that these were the principal corridors of transit through the White Mountains. The Jefferson and Randolf sites seem to be positioned for easy travel toward the Androscoggin River and eventual access to Munsungun Lake and the chert quarries located there. This route would pass under the shadow of Mount Jasper in Berlin and directly through the Vail and Adkins sites. Traffic among these sites with northern Maine is an inescapable conclusion and travel along the major drainages seems very likely. The Intervale and Colebrook sites are not on or near the Androscoggin corridor, but they do overlook major waterways. Intervale Park, the reported locale of the find, is situated near a spectacular overlook with a commanding view of the Saco River and the Mount Washington Valley, just south of the Presidential Range. Immediately north of this location, one could proceed up to the Ellis River to Pinkham Notch then down the Peabody River to its confluence with the Androscoggin. Alternatively, one could stay on the main stem of the Saco and proceed northwest through Crawford Notch into the Ammonoosuc drainage to the Connecticut. Going down stream on the Saco from Intervale would deliver the traveler to southwestern Maine. The Colebrook site is positioned within $50 \mathrm{~km}$ of the northern headwaters of the Connecticut River drainage, and of all of the Paleoindian sites of northern New Hampshire, is the one most closely related to a major waterway. All of the sites therefore share an association with riverine oriented travelways. The presence of the sites along the waterways is not unexpected, and the challenge is to determine which sites on the routes were destinations and which were encampments along the way. Mount Jasper would appear to be a significant destination, while the Colebrook site has the appearance of a one night stop. Much has been made regarding whether or not Paleoindian settlement patterns involved lithic procurement as embedded within seasonal patterns of movement for subsistence purposes, as suggested by Curran and Grimes (1989) or if the acquisition of raw material was “... logistic, accomplished by small task groups journeying to the quarries, and not embedded in the subsistence cycle" (Spiess et al., 1998: 251). The Israel River Complex presents interesting data regarding this question and analysis of its lithic assemblage, in the context of the local raw material, may help provide answers. It is clear that 
there are a variety of Paleoindian sites present in the White Mountains and that they represent distinct elements of a larger settlement pattern.

The second aspect common to nearly all of the sites is the demonstrated or highly probable presence of Munsungun chert. This chert is present either as fluted points or as channel flakes at all of the Jefferson sites, Intervale and Colebrook. No Paleoindian diagnostic artifacts have been reported in the literature from Mount Jasper, but there are several end scrapers and retouched flakes made of apparent dusky red Munsungun chert in the collection held by the Berlin Public Library (personal observation). It is distinctly possible that Paleoindian people were at Mount Jasper subsequent to acquiring tools made of the northern Maine material. The single find at Randolf appears not to be made from Munsungun chert and stands as the only exception to the pattern. Munsungun chert assumes a highly visible role in the Paleoindian not only for northern New Hampshire but also for most of New England. A key to understanding the Paleoindian settlement patterns as well as lithic technology lies with determining how and when this material was put into use. The White Mountain Paleoindian sites highlight the geographic distribution of the material and reflect its regional importance. It should be noted, however, that most of the sites contain only a very small percentage of Munsungun artifacts within the assemblages as a whole. Debitage in particular seems to be very rare, although end stage fluted points are proportionately much more common among finished tools. This assessment of the raw material must be cautioned by the fact that most of the identifications focus on the dusky red variety. The black or nearly black varieties, which are more common, are much more difficult to distinguish from other black cherts.

The common occurrence of Munsungun chert on Paleoindian sites follows a well accepted truism for sites of this age throughout the Northeast. That is, high proportions of exotic raw materials are virtually a diagnostic trait for Paleoindian sites. The only exception seems to be for sites that are found in the immediate vicinity of such a high quality source. This then may explain the distinctiveness of the Israel River Complex with its overwhelming presence of native rhyolite. The comparative convenience of its accessibility may have proven to be the key factor in the selection of site location for the highly mobile bands. The fact that apparently no later groups used these sites suggests that the locations were no longer attractive either because the raw material was hidden by established vegetation or that the resource had been effectively exhausted by the Paleoindian stone workers. For whatever reason, the Jefferson sites were not reoccupied and that may be the greater unusualness of the sites.

The Mount Jasper site is an example of a geographically restricted lithic source. Although previous excavations there have not identified Paleoindian artifacts, its status as a Paleoindian site is confirmed through the use of this material for the manufacture of fluted points that have been documented elsewhere in New England. The distribution of Mount Jasper rhyolite has implications analogous to the Munsungun distribution regarding settlement and chronology. Identification at
Paleoindian sites by Pollock indicates that it routinely cooccurs with Munsungun chert on several sites, which would support an hypothesis that these two source areas were linked in an extensive and possibly long term pattern. It is also possible that the use of the Mount Jasper material varied over time and that might be reflected in the differential use of the material. An evaluation of the proportion of Gainey style versus Barnes style points made from Mount Jasper rhyolite could reveal important trends within the Paleoindian era.

Assessment of the internal chronology of Paleoindian in the White Mountains is not possible with the available data. While most of the stylistically diagnostic points appear to be Barnes type points, the number of examples is so small that bias due to sampling size is a very real probability. Distinction between Gainey and Barnes forms is empirically demonstrable, and in broad terms their distribution by site in the Northeast seems to be mutually exclusive. What remains to be demonstrated is the time span for each style and the degree, if any, of temporal overlap or transition. Thus far the broad strokes of the chronology have been derived from research in southwestern Ontario, Michigan and, based upon distribution studies, the sequence has been deciphered. The expression of the sequence in New England still lacks an adequate time frame, however, despite the best efforts of Spiess, Wilson and Bradley. Especially frustrating is the distortion of radiocarbon date between 10,000 and 11,000 radiocarbon years ago and the evident expansion into the region by Paleoindians at about that time. It appears that approximately 1400 calendar years are compressed into 400 radiocarbon years occurring between 10,200 to 10,600 radiocarbon years ago (Curran, 1996: 5) which clearly creates an immense problem for determining the age of sites and associated artifacts as well as for unraveling the issue of the first peopling of the Northeast. Compounding this problem is the difficulty in merely obtaining carbon samples in firm association with Paleoindian materials and features. The Jefferson II site produced a date unacceptably young to be associated with the fluted points from the site and, quite likely, from a non-cultural origin. Other sites in till deposits are apt to have the same problem. The Colebrook site rendered a comfortable date of 10,290 radiocarbon years, but one which is within the period of compressed dates. Lack of a clear chronology fatally undermines most analyses that seek to compare sites within the region. Even the contemporaneity of sites with seemingly equivalent dates must be questioned. This thoroughly frustrates identification of settlement patterns and refinements of projectile point chronologies. What is needed to resolve this problem is a well stratified site with stylistically distinct Paleoindian artifacts in undisturbed dated features. Such a site is the Holy Grail of Northeastern Paleoindian research.

The other major research need is to develop an understanding of the relationship of the climate, and more specifically climatic change, with the arrival of the first people in the region and their adaptations through the Paleoindian period. Again, the issue of chronology haunts us. How quickly did the landscape change upon the recession of the glaciers 
and what was the environment like when encountered by the first colonists? Did they arrive before the Younger Dryas and endure its millennium plus deep freeze? Did they immigrate during the Younger Dryas, if so, just what was the nature of the environment then, and how and why did people move into the region? Alternatively, might new immigrants have arrived at or near the end of the climatic reversal, pouring into the area as flora and fauna rapidly re-colonized the opening environmental niche? The latter proposal would require rejecting some dates from well known sites, but this might not be so unreasonable given the uncertainty of radiocarbon assays during this period. Regardless, once the Younger Dryas was over, how did the environment change and what were the responses of the inhabitants? Some resources would have disappeared while others were made newly available. I have suggested that use of Jefferson rhyolite in the Israel River valley was affected by the vegetation cover. However, the use of Mount Jasper rhyolite would not have been so constrained. Glacial lakes were present throughout the White Mountains. Some drained rapidly, probably before human occupation, but others could have persisted behind debris dams. What role, if any, did the lakes play in constraining or directing patterns of settlement and subsistence in the region? We strongly suspect that caribou played a major role in the subsistence regime. At what point were caribou reduced in numbers such that they were no longer a reasonable target for food and hides? Was this reduction a natural consequence of the changing environment only, or were they extirpated by human predation. This brings us to the end of the Paleoindian occupation of the White Mountains. Is the lack of a Late Paleoindian (i.e. nonfluted, Plano-like point making) tradition real, or a consequence of a small and biased sample size. Such sites are found to the east and north. Might we conclude that the terminal Paleoindian culture shifted ever northward, culminating the tradition on the Gaspe Peninsula at sites such as Rimouski and LaMarte? Thankfully, the question of the transition from Paleoindian to Archaic is beyond the scope of this paper, since the Early Archaic is much more poorly documented in northern New Hampshire than is Paleoindian. Still, environmental change with the onset of the Holocene must have played an important role in that change.

All of these issues regarding climatic and cultural change require both a sound understanding of the environment in the various geographic settings and, more importantly, the ability to associate specific archaeological sites with these environments. Unfortunately, we have yet to recover artifacts in bogs and bottoms of ponds where pollen and macrofloral fossils are found in stratigraphic context. Most sites are stranded on sands or till deposits where preservation of organic materials is negligible. The inability to confidently associate specific human occupations with particular environmental and climatic data has been a problem second only to the crisis in chronology. The best we have been able to produce has been the occasional identification of plant species from charcoal in hearths and the rare identification of an animal species from a calcined bone fragment. A solution, though only partial, will be to assemble environmental data from sources as close as possible to known, or reasonably suspected locations of, Paleoindian sites. When more reliable dates are obtained from archaeological contexts, they could then be assessed in the context of the growing body of climatic and environmental data. The weak link in this chain of data is the association of the archaeological data with the environmental. Forging a stronger link will require improvement of environmental data recovery from cultural contexts, and lies squarely within the domain of the archaeologist. The solution is not impossible, just difficult.

\section{CONCLUSIONS}

We have been able to identify seven Paleoindian sites at five localities in or very near to the White Mountains. They have similarities in content and gross environmental setting, that allow us to speculate on broad patterns and to construct some general explanations which might have some utility for interpreting these sites and identifying new ones. Yet each also has a set of very distinctive differences which ought to caution us against speculating too freely, or at least rigidly adhering to those conclusions, because new data will almost surely require substantial revision. New data, especially on the age of the sites and paleoenvironment are definitely needed. The research so far has accumulated intriguing information, but only at the individual site level. Our ability to generalize is left at a superficial and descriptive level. To a large extent this is because the range of the raw data is so limited, with almost nothing in terms of organic remains that would provide a fuller view of daily life and, more critically, the nature of the climate and environment. Even where the data are reasonably complete, i.e. the lithic technological aspects, the difficulty in addressing comparative issues is severely hampered by a virtual lack of chronological control and knowledge of the site specific environmental setting. We can marvel at the technological expertise of the maker of the Intervale Point, reconstruct the behavior of the knapper(s) at the Colebrook site, or speculate on the dynamics of tool manufacture, use, discard and replacement in the Israel River Valley but fall short of identifying what were these people hunting, in what season, in groups of what size. We do not know when they arrived in the region or how their culture faded from the scene. We know that they ranged all across New England, but we have no sense as to whether their presence in the White Mountains was incidental or central to their travel. We are certain that they were well adapted to a harsh environment, highly skilled in survival in an Arctic-like setting. But this was not the Arctic, and we need to take into account the unique aspects of the early post-glacial world in the temperate latitudes. The Paleoindian occupation of the White Mountains is a fresh and intriguing topic of study with implications on a regional and even continental scale.

\section{REFERENCES}

Bayly, S.L. and Boisvert, R.A.,1995. White Mountain National Forest uplands ponds Prehistoric archaeological survey. Technical report submitted to United States Forest Service, White Mountains National Forest, Laconia, $129 \mathrm{p}$. 
Billings, M.P., 1953. Correspondence addressed to John Q. Stewart, February 11. Copy on file at the NH Division of Historical Resources, Concord, $2 \mathrm{p}$.

Billings, M.P. and Fowler-Billings, K.,1975. Geology of the Gorham Quadrangle New Hampshire-Maine. Bulletin 6. New Hampshire Department of Resources and Economic Development, Concord, $120 \mathrm{p}$.

Boisvert, R.A., 1992. The Mount Jasper lithic source, Berlin, New Hampshire: National register of historic places nomination and commentary. Archaeology of Eastern North America, 20: 151-166.

1998a. The Israel River Complex: A Paleoindian manifestation in Jefferson, New Hampshire. Archeology of Eastern North America 26: $97-106$.

1998b. Intervale Fluted Point. New Hampshire Archeological Society Newsletter, 14: 5-8.

Boisvert, R.A. and Dickinson, D.W., 1992. Current research in lithic sources in New Hampshire: The view from Mt. Jasper, Berlin. Paper presented at the New England Anthropological Association Semi-Annual Meeting, Bridgewater, $12 \mathrm{p}$.

Bonnichsen, R., Keenlyside, D and Turnmire, K, 1991. Paleoindian patterns in Maine and the Maritimes, p 1-36. In Prehistoric Archaeology in the Maritime Provinces: Past and Present Research. Reports in Archeology 8. The Council of Maritime Premiers-Maritime Committee on Archaeological Cooperation, $329 p$.

Bouras, E.F. and Bock, P.M., 1997. Recent paleoindian discovery: The first people in the White Mountain region of New Hampshire. The New Hampshire Archeologist, 37: 48-58.

Bunker, V., Feighner, E. and Potter, J., 1997. Technical Report Archeologica Resources Phase I-B Preliminary Archeological Assessment and Phase II Intensive Survey. Portland Natural Gas Transmission System Northern New Hampshire Revision Route M.P. 0.0-Docket No. CP 96-249-003. Unpublished report on file at the $\mathrm{NH}$ Division of Historical Resources, Concord.

Carty, F.M. and Spiess, A.M.,1992. The Neponset Paleoindian Site in Massachusetts. Archaeology of Eastern North America, 20: 19-38.

Curran, M., 1996. Paleoindians in the Northeast: The problem of dating fluted point sites. Review of Archaeology, 17(1): 2-5.

Curran, M. and Grimes, J.R., 1989. Ecological implications for Paleoindian lithic procurement economy in New England, p. 41-74. In C.J. Ellis and J.C. Lothrup, ed., Eastern Paleoindian Lithic Resource Use. Westview Press, Boulder.

Ellis, C. and Deller, D.B., 1988. Some distinctive Paleo-Indian tool types from the lower Great Lakes Region. Midcontinental Journal of Archaeology, 13: 111-158.

Gramly, R.M., 1980. Raw material source areas and 'curated' tool assemblages. American Antiquity, 45: 823-833.

1982. The Vail Site: A Palaeo-Indian encampment in Maine. Bulletin of the Buffalo Society of Natural Sciences, 30,169 p.

1984. Mt Jasper: A direct access lithic source area in the White Mountains of New Hampshire, p 11-21. In J.E. Ericson and B.A. Purdy, ed., Prehistoric Quarries and Lithic Production. Cambridge University Press.

1988. The Adkins Site: A Palaeo-Indian Habitation as Associated Stone Structure. Persimmon Press, Buffalo, $119 \mathrm{p}$.

Gramly, R.M. and Cox, S.L.,1976. A prehistoric quarry and workshop at Mt. Jasper, Berlin, Man in the Northeast, 24: 121-134.
Hall, D.H., 1997. Corrected radiocarbon calendar can clarify peopling of Americas. Mammoth Trumpet, 12(4): 1,4-7.

Hart, H.C., 1948. Correspondence addressed to Froelich Rainey, September 2. Copy on file at New Hampshire Division of Historical Resources, Concord, $1 \mathrm{p}$.

Lougee, R.J., 1930. The origin and occurrence of glacial washed deposits in the White Mountains region. Unpublished manuscript based on field work for the New Hampshire Highway Department. Baker Library Archives, Dartmouth College, Hanover, $26 \mathrm{p}$.

Meltzer, D.K., Grayson, D.K., Ardilla, G., Barker, A., Dincauze, D.F., Haynes, C.V., Mena, F., Nunez, L. and Stanford, D., 1997. On the Pleistocene antiquity of Monte Verde, Southern Chile. American Antiquity, 62(4): 659-663.

Mounier, R.A., Cresson, J. and Martin, J.W. 1993. New evidence of Paleoindian biface fluting from the outer coastal plain of New Jersey. Archaeology of Eastern North America, 21: 1-24.

Morrow, J., 1997. Clovis-Gainey-Folsom: Variation in fluted biface technologies. Paper presented at The Folsom Workshop: A Conference on Prehistoric Replicative Folsom Knapping. University Texas at Austin. March 18-22, 1997, 18 p.

Pelcin, A., 1998. The Successful Removal of a Folsom Channel Flake: The Role of the Angle of Blow. Paper presented at the 63rd Annual Meeting of the Society for American Archaeology, Seattle, $6 \mathrm{p}$.

Pollock, S.G., Hamilton, N. and Boisvert, R.A., 1996. The Mount Jasper lithic source, Berlin, New Hampshire, p. 245-253. Guidebook to Field Trips in Northern New Hampshire and Adjacent Regions of Maine and Vermont. New England Intercollegiate Geological Conference, 88th Annual Meeting, $367 \mathrm{p}$.

Pollock, S.G., Hamilton, N. and Boisvert, R.A.,1998. The Berlin lithic source is a rhyolite dike near Berlin, New Hampshire: Its exploitation by Paleo and Archaic peoples. Paper presented at the Geological Society of America 33rd Annual Meeting Northeastern Section, Portland, Maine, $6 \mathrm{p}$.

Price, C.B., 1967. The Indian trails of New Hampshire. New Hampshire Archeologist, 14, $26 \mathrm{p}$.

Sargent, H.F. and Ledoux, F.G., 1973. Two fluted points from New England. Man in the Northeast, 5: 67-68.

Simmons, D.B., Schott, M.J. and Wright, H.T.,1984. The Gainey Site: Variability in a Great Lakes Paleo-Indian assemblage. Archaeology of Eastern North America, 12: 266-279.

Spiess, A.F., 1990. Two isolated Paleoindian artifacts from Maine. Archaeology of Eastern North America, 18: 65-74.

Spiess, A.F. and Wilson, D.B., 1987. Michaud: A Paleoindian site in the New England-Maritimes region. Occasional Publications in Maine Archaeology 6. The Maine Historic Preservation Commission and the Maine Archaeological Society, Augusta, $232 \mathrm{p}$.

Spiess, A.F., Wilson, D.B. and Bradley, J.W., 1998. Paleoindian occupation in the New England-Maritimes region: Beyond cultural ecology. Archaeology of Eastern North America, 26: 201-264.

Thompson, W.B., Fowler, B.K., Flanagan, S.M. and Dorion, C.C., 1996. Recession of the late Wisconsinan ice sheet from the northwestern White Mountains, New Hampshire, p. 203-234. In M. R. Van Baalen, ed. Guidebook to Field trips in Northern New Hampshire and Adjacent Regions of Maine and Vermont. Harvard University, 367 p.

Wilson, D.B. and Spiess, A. E., 1990. Study Unit 1: Fluted point Paleoindian. Maine Archaeological Society, Bulletin, 30: 15-31. 